\title{
Thermoregulation in Colonies of Africanized and Hybrids With Caucasian, Italian and Carniolan Apis mellifera Honey bees
}

\author{
Vagner de Alencar Arnaut deToledo ${ }^{1} *$ and Regina Helena Nogueira-Couto $^{2}$ \\ ${ }^{1}$ Department of Animal Science at the Universidade Estadual de Maringá, Colombo, Av. 5790, 87020-900, Maringá (PR) \\ Brazil. ${ }^{2}$ Faculdade de Ciências Agrárias e Veterinárias (FCAVJ), Jaboticabal - UNESP - Rod. Carlos Tonanni, km5, \\ 14870-000, Jaboticabal (SP) Brazil.
}

\begin{abstract}
This experiment was carried out to study the internal temperature regulation of a colony of Africanized honey bees (AFR), compared with hybrid Caucasian (CAU), Italian (ITA), and Carniolan (CAR) bees, during the period of one year and different size hives located in a sub-tropical region. The instant internal temperature, $33.7 \pm 1.5^{\circ} \mathrm{C}$ for the AFR, $33.5 \pm 1.4^{\circ} \mathrm{C}$ for the $C A U, 33.7 \pm 1.5^{\circ} \mathrm{C}$ for the ITA and $33.8 \pm 1.4^{\circ} \mathrm{C}$ for the $C A R$, did not show any significant difference $(P>0.05)$. The maximum temperature $\left(36.1 \pm 2.3^{\circ} \mathrm{C}\right)$ was statistically different $(P<0.05)$ from the minimum $\left(27.6 \pm 5.3^{\circ} \mathrm{C}\right)$. There was no difference $(P>0.05)$ in the mean internal temperature, between the nucleus $\left(31.7 \pm 6.3^{\circ} \mathrm{C}\right)$ and the brood nest $\left(32.1 \pm 5.3^{\circ} \mathrm{C}\right)$ measured between two and four $o^{\prime}$ clock in the afternoon.
\end{abstract}

Key words: Temperature, honey bee, Apis, thermoregulation, hive, hybrids

\section{INTRODUCTION}

Thermoregulation in Apis mellifera colonies occurs due to the clustering of large quantities of bees, especially in the central broodnest area (Southwick, 1987), resulting in a higher and more uniform temperature in this region (mean of 24.1 $\pm 0.8^{\circ} \mathrm{C}$, Dunham, 1933). On the other hand, the temperature in non-brooding areas is more variable (Dunham, 1933).

Thermoregulation activity is carried out by a microvibration of the thoracic muscles which produces heat (Roth, 1965), and is performed by the nurse bees from the fifth day (Hepburn et al., 1984). The adult bees are responsible for the thermoregulation of the colony, therefore, their distribution in the nest, along with the metabolism of the brood, which varies according to the stage of development, may cause temperature differences (Levin \& Collinson, 1990).
Büdel (1955) found, in areas with egg-larvae, higher temperatures than in areas with pupae, which in turn, had higher temperatures than those observed in empty cells. This higher temperature was related to the presence of nurse bees.

According to Darchen (1983), African honey bees from Gabon are inferior to European honey bees in their temperature regulation capacity in the brood area. Woyke (1973) confined A. m. adansonii colonies at $0-4^{\circ} \mathrm{C}$ and after three months they began to die, showing that they were unable to survive at low temperatures. However, (Fletcher, 1978) stated that the results from a given region should not be extrapolated to the bees of other African regions, as different races are involved.

W-Worswick (1987) studied thermoregulation in A. $m$. adansonii Latreillle and A. m. capensis Escholtz, and concluded that the African honeybee A. $m$. adansonii needed a smaller number of bees in the cluster to maintain the internal temperature.

*Author for correspondence 
This experiment aimed to verify the maintenance of the internal temperature of the Africanized honeybee colony comparatively with Caucasian, Italian and Carniolan hybrid bees during a year, in different size hives, in a sub-tropical region.

\section{MATERIALS AND METHODS}

In the first stage, 22 colonies of hybrid honey bees, installed in Langstroth model hives, with 10 combs, daughters of queens which were introduced as virgins and fertilized in the air, by Africanized males, were used. The queens used were: Africanized (AFR - five colonies), Caucasian (CAU - five colonies), Italian (ITS - six colonies) and Carniolan (CAR - six colonies). These colonies were homogenized at the beginning of the experiment for the brood area (worker eggs, larvae and pupae) and food (honey and pollen).

After verifying the external temperature, measured in the shade in the apiary, the internal temperature of each colony was taken, at two and four o'clock in the afternoon. A mercury Celsius thermometer with accuracy of $\pm 1^{\circ} \mathrm{C}$ was inserted through the hive lid in the middle of the brood combs for about a minute. Twenty-one observations were made at intervals of approximately eight days, during 172 days $(05 / 18 / 89$ to $11 / 05 / 89)$.

In the second stage, eight colonies of offspring from Africanized queens which were introduced as virgin and fertilized in the air, four being placed in a nucleus with four combs; two with brood and two with food, were used. The remaining four were placed in broodnest hives with 10 combs; four with brood, four with food and two empty. Both the nucleus and the broodnest were the Langstroth type. The wood made in hives construction was cedar. Each hive was painted of blue color oil paint. In all hives, there was used asbestos tile as hive cover. A maximum-minimum thermometer was inserted between two brood combs, which remained in the hive until the end of the experiment. The maximum, minimum and instant (at two and four o'clock p.m.) temperature data were collected at an interval of approximately seven days. This stage lasted 341 days $(03 / 21 / 93$ to 02/25/94).
In this second stage, the hives were weighed four times (on 08/21, 10/22, 12/23/93 and 02/25/94) during the day without bees and during the night with bees to estimate the weight of the swarm. Besides, 22 workers bees from each colony were weighed individually to estimate the weight of each bee and then to get the number of adult bees in each of the hives.

The climatic data (maximum, minimum and mean temperature $-{ }^{\circ} \mathrm{C}$, relative humidity - $\%$ and rainfall - $\mathrm{mm}$ ) were provided by the FCAVJ - UNESP Weather Station, located approximately 900 meters from the Apiculture Section. The following standards were adopted in the analysis: In the first stage, each colony made up a plot and each hybrid a treatment; the AFR were treatment one (T1), the CAU, two (T2), the ITA three (T3), and CAR, four (T4). Variance and Partial Correlation analysis were done using the GLM and Stepwise procedures from S.A.S. (Statistical Analysis System - 1994). The Stepwise procedure analysis the relative importance of each independent variable effect (temperature, relative humidity, rainfall) over the dependents (hybrids and internal temperature). In the second step, variance analysis using the GLM procedure from S.A.S. (Statistical analysis System - 1994), were performed.

\section{RESULTS AND DISCUSSION}

In the first stage, the variance analysis showed that the daily internal temperature did not differ significantly among the hybrids studied; the general mean was $33.7 \pm 1.4^{\circ} \mathrm{C}$, close to that obtained by (Dunham, 1933). The mean temperature for each hybrid was: AFR, $33.7 \pm$ $1.5^{\circ} \mathrm{C}$; CAU, $33.5 \pm 1.4^{\circ} \mathrm{C}$; ITA, $33.7 \pm 1.5^{\circ} \mathrm{C}$ and CAR $33.8 \pm 1.4^{\circ} \mathrm{C}$. The mean external temperature during the observation period was $20.6 \pm 2.8^{\circ} \mathrm{C}$.

The temperature varied from $31.1(09 / 25 / 89)$ to $35.8^{\circ} \mathrm{C}(10 / 21 / 89)$, for the AFR; from 31.6 $(05 / 25 / 89)$ to $36.6^{\circ} \mathrm{C}(10 / 21 / 89)$ for the CAU; from $31.4(05 / 18 / 89)$ to $36.1^{\circ} \mathrm{C}(10 / 21 / 89)$ for the ITA and from $31.7(05 / 18 / 89)$ to $36.9^{\circ} \mathrm{C}$ $(11 / 05 / 89)$ for the CAR. 
In colonies submitted to high environmental temperatures, Lensky (1964) reported a temperature of $37.6^{\circ} \mathrm{C}$ inside a hive, while Miwnick and Murphey (1974) reported $34.0^{\circ} \mathrm{C}$, and SAKAY et al. (1976) $35.0 \pm 1.0^{\circ} \mathrm{C}$. Kronenberg and Heller (1982) reported temperatures higher than $30.0^{\circ} \mathrm{C}$ with low environmental temperatures (between -1.0 and $14.0^{\circ} \mathrm{C}$ ). Brandeburgo (1986), reported an annual variation between 34.2 and $36.4^{\circ} \mathrm{C}$ in the internal temperature of Africanized colonies in the region of Ribeirao Preto. Núñez (1979) found that by artificially heating and cooling the hive, European and Africanized honey bees were able to maintain the temperature in the broodnest area stable within 1 or $2^{\circ} \mathrm{C}$ in the presence of large external temperature variation.

Figure 1 shows that the internal temperature fluctuations obtained from two to four p.m. were similar among the four treatments, suggesting that the factors that affected this variable acted similarly on these hybrids. The mean internal temperature was $13.4^{\circ} \mathrm{C}$ higher than the mean external temperature. Figure 1 also shows that the internal temperature regulation was efficient, even in situations with sudden rises and falls in external temperature.

The results showed that even in the winter period, all the hybrids maintained their high mean internal temperature at the studied time. It is possible that a reduction in metabolism with a lower heat production eases the maintenance of the colony during the winter, with a lower expenditure of its energetic reserves. It can be explained because in Brazil the winter period is different than Canada or Northern Europe (temperate zones), with a long dry period and low temperatures in some days. The internal and external temperatures correlated positively (determination coefficient $\mathrm{R}^{2}=0.2363$; $0.2881 ; 0.2235$ and 0.2277 ) and negatively with the relative humidity $\left(\mathrm{R}^{2}=0.0974 ; 0.0513 ; 0.0799\right.$ and 0.0925) respectively, for the AFR, CAU, ITA and CAR, showing the importance of relative humidity in the regulation of the hive temperature. Reduction in the colony temperature carried out by the workers is also due to water collection and evaporation (Free, 1980).

In general, in the second stage the mean internal temperature, including the maximum and the minimum was $31.9 \pm 5.6^{\circ} \mathrm{C}$, which was $1.8^{\circ} \mathrm{C}$ below to that obtained in the first stage. The means of the maximum and minimum temperatures obtained from nucleus hives of Africanized honey bees were $36.1 \pm 2.4^{\circ} \mathrm{C}$ and $27.4 \pm 4.9^{\circ} \mathrm{C}$ and those of the broodnest, $35.6 \pm 1.3^{\circ} \mathrm{C}$ and $28.6+5.5^{\circ} \mathrm{C}$, respectively. The internal temperature variation was lower in the hive broodnest than in the nucleus. There was no statistical difference $(\mathrm{P}>0.05)$ among nucleus hives and broodnests for the maximum and minimum internal temperatures. The mean maximum temperature $\left(35.9 \pm 1.9^{\circ} \mathrm{C}\right)$ was statistically different $(\mathrm{P}<0.05)$ from the mean minimum $\left(28.0 \pm 5.2^{\circ} \mathrm{C}\right)$ and was influenced by the month of data collection.

Figure 2 shows there was a large variation between the maximum and minimum temperatures in the winter. The extreme values of the maximum and minimum temperatures were $47.0^{\circ} \mathrm{C}$ in a nucleus and $10.0^{\circ} \mathrm{C}$ in brood nest, when the mean external temperatures were $26.2^{\circ} \mathrm{C}$ and $23.1^{\circ} \mathrm{C}$, respectively. This finding is different from the literature data on internal temperature regulation in A. mellifera honey bees, where small variations of one or two, or a maximum of three degrees are reported in the broodnest area (Southwick and Heldmaier, 1987; Villa et al., 1987). There was no difference in the mean internal temperature between the nucleus $\left(31.8 \pm 5.8^{\circ} \mathrm{C}\right)$ and broodnest $\left(32.1 \pm 5.3^{\circ} \mathrm{C}\right)$ measured from two to four p.m. However, the temperatures obtained in both the nucleus and the broodnest in the second stage, were lower than those of broodnests in the first stage.

It is possible that the observed reduction in the number of workers at the end of the experiment comparatively with that at the beginning may have been responsible for the greater variation obtained 
Figure 1. External and internal hive temperature for Africanized Apis mellifera bees (AFR), Caucasian (CAU), Italian (ITA) and Carniolan (CAR), taken from 05/18/89 to 11/05/89.

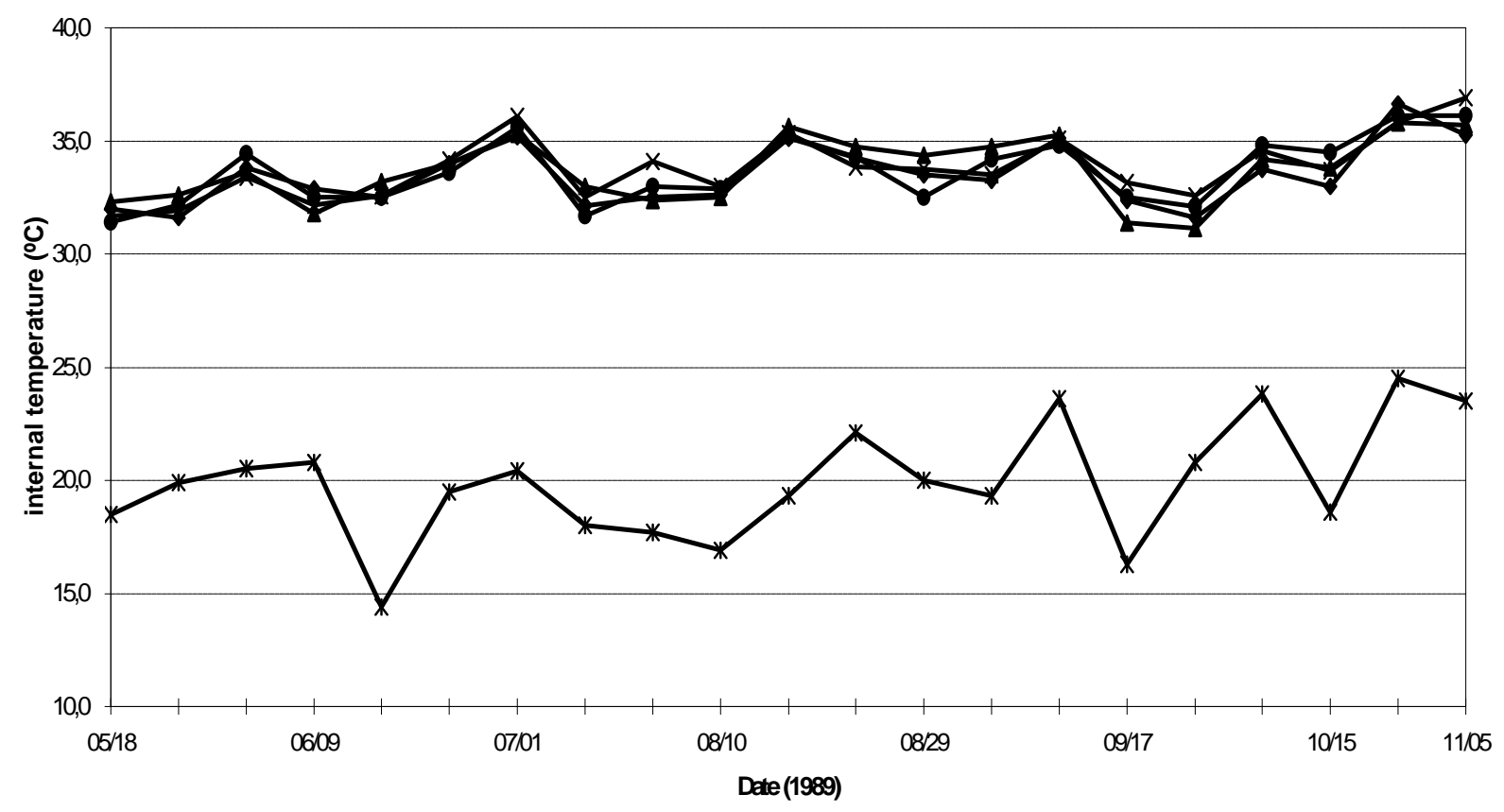

$\rightarrow \mathrm{AHB} \sim \mathrm{CAU} \rightarrow-\mathrm{TA} \rightarrow \mathrm{CAR} \rightarrow$ *extemal temperature

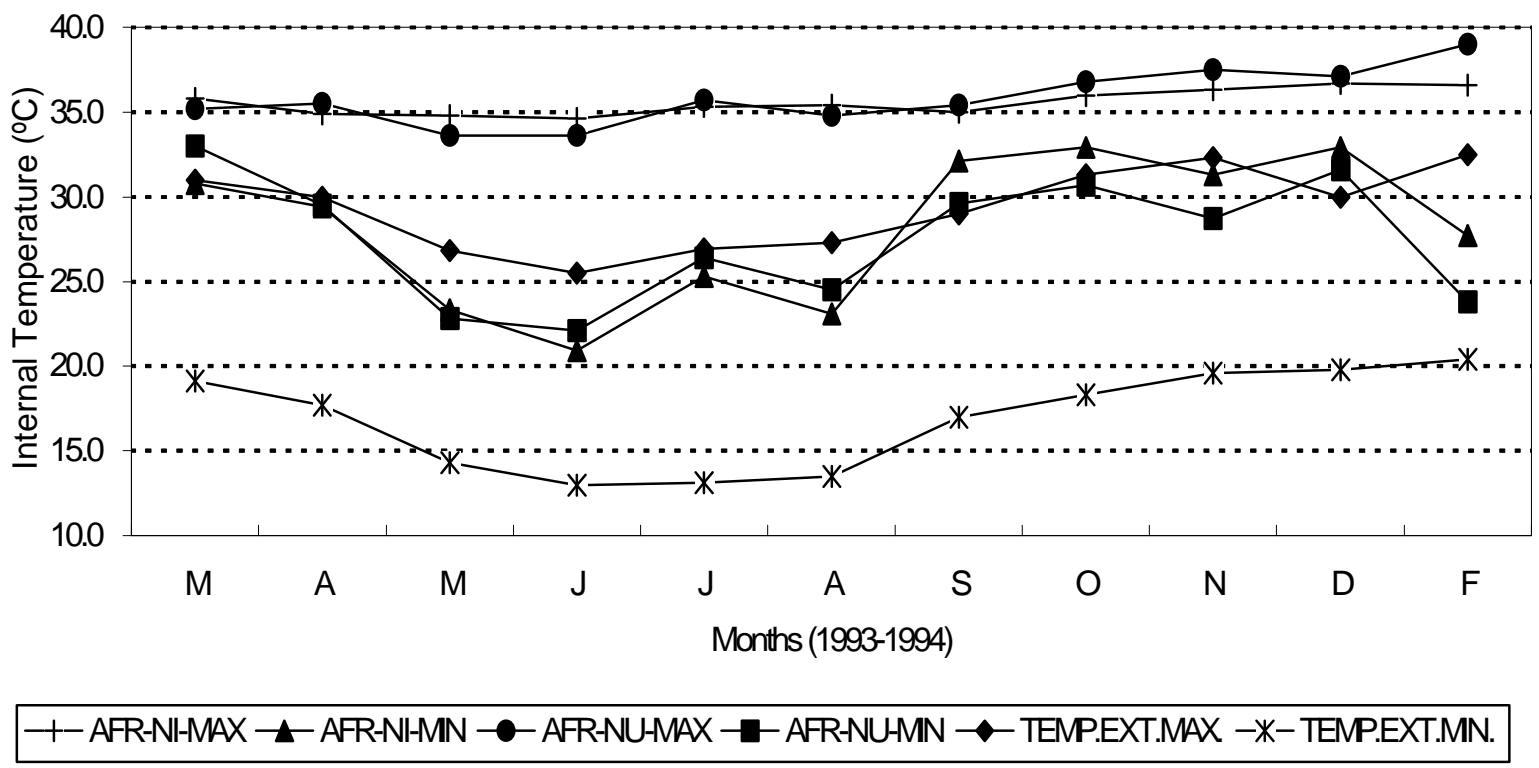

Figure 2. Internal and external (EXT - 1C) maximum (MAX) and minimum (MIN) temperature (TEMP) of broodnest (NI), nucleus (NU) hives of Africanized Apis mellifera bees (AFR) from March 1993 to February 1994. 
between the maximum and minimum temperatures. Of course, the reduction in the nectar and pollen flow explains the reduction in the number of workers bees. But it is different of Free (1980) who said small groups of 25 to 200 bees are able to maintain their temperature higher than that of the environment.

Data in Table I shows that, on average, the nucleus and broodnests had statistically different $(\mathrm{P}<0.05)$ numbers of honey bees, 8,724 $\pm 4,569$ and 22,860 $\pm 9,005$, respectively. The general mean number of honey bees was $16,100 \pm 10,107$. This table also shows that the mean maximum and minimum internal temperatures of each hive varied independently from the number of adult bees and from the type of hive. This variation was probably caused bychanges in the external temperature. This mean number of bees in the nucleus hives had a correlation (Pearson coefficient) of 0.7712 with the minimum external temperature $(\mathrm{P}<0.05)$. This did not happen with the maximum external temperature which did not correlate with nucleus or brood nests number of bees. The mean weight of the workers taken from the nucleus was $82.8 \pm$ $13.5 \mathrm{mg}$, which did not differ statistically $(\mathrm{P}>0.05)$ from the average weight of the workers from the broodnests $(85.4 \pm 7.7 \mathrm{mg})$; the general mean was $84.1 \pm 11.1 \mathrm{mg}$. According to Free (1980), small groups of 25 to 200 bees are able to maintain their temperature higher than that of the environment by increasing their metabolism and food consumption.

The variation of the maximum and minimum temperatures was greater when the population was small, regardless of the hive size used (broodnest or nucleus).

Table 1. Estimate of the mean number of adult worker honey bees and maximum and minimum internal temperature $\left({ }^{\circ} \mathrm{C}\right)$ in the 4-frame nucleus and full size 10-frame hives.

\begin{tabular}{|c|c|}
\hline & $\begin{array}{c}\text { Estimate of the mean number of adult worker bees } \\
\text { (mean maximum and minimum temperature) }\end{array}$ \\
\hline & mean and standard deviation \\
\hline Nucleus no 28 & $\begin{array}{c}6370 \pm 5405 \\
(35,3 \pm 1,3 \text { e } 27,8 \pm 5,5)\end{array}$ \\
\hline Nucleus no 29 & $\begin{array}{c}8178 \pm 4158 \\
(36,4 \pm 1,5 \text { e } 30,1 \pm 4,9)\end{array}$ \\
\hline Nucleus no 30 & $\begin{array}{c}12593 \pm 682 \\
(36,2 \pm 0,8 \text { e } 30,0 \pm 1,7)\end{array}$ \\
\hline Hive $n^{0} 2$ & $\begin{array}{c}24595 \pm 11156 \\
(36,8 \pm 0,5 \text { e } 28,0 \pm 6,2)\end{array}$ \\
\hline Hive $n^{0} 6$ & $\begin{array}{c}24516 \pm 8143 \\
(35,0 \pm 0,8 \text { e } 31,1 \pm 4,4) \\
\end{array}$ \\
\hline Hive $n^{\circ} 16$ & $\begin{array}{c}19470 \pm 2057 \\
(36,0 \pm 1,2 \text { e } 28,0 \pm 7,4)\end{array}$ \\
\hline
\end{tabular}

Figure 2 shows that the maximum temperature obtained had less variation than the minimum, although both were higher than the environment temperature. Free (1980) and Southwick (1988) reported that the comb, especially the empty one was very important in the temperature balance, due to its low heat conductivity. This means that from the moment in which the comb receives heat it loses it only slowly, and acts as a favorable factor in the maintenance of the internal temperature of the colony.

An analysis of the instant internal temperature was also carried out (at two and four 4 p.m.) when the 
maximum and minimum temperatures were taken. The analysis of these data showed a difference $(\mathrm{P}<0.05)$ between the nucleus and the broodnest. The instant mean temperature was $36.7 \pm 3.6^{\circ} \mathrm{C}$ and $35.2 \pm 0.8^{\circ} \mathrm{C}$ in the nucleus and nest, respectively; the general mean was $35.9 \pm 2.5^{\circ} \mathrm{C}$. All these values were higher than the means obtained in the first stage, for all the hybrids. This showed the importance of taking the internal maximum and minimum temperatures of a colony to check which is the real variation. Furthermore, the hive nucleus, although with a lower capacity and also a lower bee number, was maintained at a higher temperature than the broodnest hive, indicating that there might be a relationship between the number of adult bees and the size of area available to them.

It may be concluded that there were no differences in instant internal temperature in the hives among the studied hybrids (Africanized, Caucasians, Italians and Carniolan) did not have differences in instant internal temperature in the hives, which varied from 31.1 to $36.9^{\circ} \mathrm{C}$, with a mean of $33.7^{\circ} \mathrm{C}$. High external temperatures increased and high relative humidity decreased the internal temperature of the hives. There was a large and statistically significant difference between maximum and minimum temperatures for the Africanized honey bees $\left(8.5^{\circ} \mathrm{C}\right)$. This variation was greater than that reported in the literature $\left(2-3^{\circ} \mathrm{C}\right)$. The internal temperature of the broodnests nucleus did not differ.

\section{ACKNOWLEDGEMENTS}

We are grateful to the technician Édio Braz Lopes, for his help in conducting the experiments, and to the CNPq and FAPESP for financial help.

\section{RESUMO}

Este experimento teve como objetivos verificar a regulação da temperatura interna da colônia de abelhas africanizadas (AFR) comparada com abelhas híbridas de caucasianas (CAU), italianas (ITA) e cárnicas (CAR), no decorrer de um ano e, em colméias de tamanhos diferentes, em região com clima subtropical. Na primeira etapa, a temperatura interna do momento não apresentou diferença significativa $(\mathrm{P}>0,05)$ entre os híbridos estudados e foi de $33,7 \pm 1,5^{\circ} \mathrm{C}$, para as AFR; 33,5 $\pm 1,4^{\circ} \mathrm{C}$, para as CAU; $33,7 \pm 1,5^{\circ} \mathrm{C}$, para as ITA e $33,8 \pm 1,4^{\circ} \mathrm{C}$, para as CAR. Na segunda etapa, a temperatura máxima $\left(36,1 \pm 2,3^{\circ} \mathrm{C}\right)$ foi diferente estatisticamente $(\mathrm{P}>0,05)$ da mínima $(27,6 \pm$ $\left.5,3^{\circ} \mathrm{C}\right)$. Não houve diferença $(\mathrm{P}>0,05)$, na temperatura interna média, entre núcleo $(31,7 \pm$ $\left.6,3^{\circ} \mathrm{C}\right)$ e ninho $\left(32,1 \pm 5,3^{\circ} \mathrm{C}\right)$, medida das 14 às 16 horas.

\section{REFERENCES}

Brandeburgo, M. A. M. (1986). Comportamento de defesa (agressividade) e aprendizagem de abelhas africanizadas: análise e correlação entre variáveis biológicas e climáticas, herdabilidade e observações em colônias irmãs. Tese de Doutorado, Faculdade de Medicina de Ribeirão Preto - USP, Ribeirão Preto (SP).

Büdel, A. (1955). Variações na temperatura do ar entre os favos em uma colônia com cria. $Z$. Bienenforsch, 3, 88-92.

Darchen, R. (1973). La thermorégulation et l'ecologie di quelques espècies d'abeilles sociales d'Afrique (Apidae, Trigonini et Apis mellifica var. adansonii). Apidologie, 4, 341370.

Dunham, W. E. (1933). Hive temperatures during the summer. Gleanings in Bee Culture, 61, 527-529.

Fletcher, D. J. C. (1978). The African bee, Apis mellifera adansonii, in Africa. Annual Review of Entomology, 23, 151-171.

Free, J. B. (1980). A organização social das abelhas (Apis). São Paulo, EDUSP, 13, 79 p.

Hepburn, H. R.; Hugo, J. J.; Mitchell, D.; Nijland, M. J. M.; Scrimgeour, A. G. (1984). The energetic costs of wax production by the African honeybee (Apis mellifera adansonii Latreille). South African Journal of Science, 80, 363-368.

Jay, S. C.; Frankson, C. E. (1972). Effects of various hive covers, shading and ventilation on honeybees in the tropics. Journal of Apicultural Research, 11, 111-115.

Kronenberg, F.; Heller, H. C. (1982). Colonial termoregulation in honeybees (Apis mellifera). 
Journal of Comparative Physiology $B$. Biochemical Systematic and Environmental Physiology, 148, 65-76.

Lensky, Y. (1964). Behaviour of a honeybee colony at extreme temperatures. Journal of Insect Physiology, 10, 1-12.

Miwnick, D. R.; Murphey, M. (1974). The effect of population density on the maintenance of cluster temperatures by the honeybee Apis mellifera L. American Bee Journal, 114, 210 211.

Levin, C. G.; Collison, C. H. (1990). Broodnest temperature differences and their possible effect on drone brood production and distribution in honeybee colonies. Journal of Apicultural Research, 29, 35-45.

Núñez, J. A. (1979). Comparative study of thermoregulation between European and Africanized Apis mellifera in Brazil. Journal of Apicultural Research, 18, 116-121.

Roth, M. (1965). Production of heat by the honeybee. Ann. Abeille, 8, 5-77.

Sakay, T.; Higo, K.; Sasaky, M. (1976). Temperature constancy of a field-built natural comb of the European honeybee. Bulletin of the Faculty of Agriculture, Tamagawa University, 16, 55-65.

Spivak, M.; Zeltzer, A.; Degrandi-Hoffman, G.; Martin, J. (1992). The influence of temperature on rateofdevelopment and color patterns of queen honey bees (Apis mellifera L.).
Environmental Entomology, 21, 364-370.

Southwick, E. E. (1988). Thermoregulation in honey-bee colonies. In: Needham, G. R.; Page Jr., R. E.; Delfinado-Baker, M.; Bowman, C. E. Africanized honey bees and bee mites. Chichester (England), Ellis Horwood Limited. p. 223-236.

Southwick, E. E.; Heldmaier, G. (1987). Temperature control in honey bee colonies. Bioscience, 37, 395-399.

Villa, J. D.; Gentry, C.; Taylor Jr., O. R. (1987). Preliminary observations on thermoregulation, clustering, and energy utilization in African and European honey bees. Journal of the Kansas Entomological Society, 60, 4-14.

Woyke, J. (1973). Experiences with Apis mellifera adansonii in Brazil and in Poland. Apiacta, 8 , 115-116.

W-Worswick, P. V. (1987). Comparative study of colony thermoregulation in the African honey bee Apis mellifera adansonii Latreille and the cape bee, Apis mellifera capensis Escholtz. Comparative Biochemistry and Physiology. A. Comparative Physiology, 86, 95-102.

Received: November 11, 1998; Revised: January 11, 1999; Accepted: May 14, 1999. 